Ragini Tharoor Srinivasan

University of California, Berkeley

Verge: Studies in Global Asias 1.2, 2015: 158-191.

\title{
The Smithsonian Beside Itself: Exhibiting Indian Americans in the Era of New India
}

Halfway through the Beyond Bollywood exhibition at the National Museum of Natural History (NMNH) in Washington, D.C., near the taxi stand and the installation of the Arch Motel, next to Vinod Dham's Pentium chip and around the corner from DJ Rekha, is Ruee Gawarikar's “The Goddess of Visas” (2013). The accompanying text panel describes the painting as "a humorous take on the tedious and anxiety-ridden process of applying for a work visa, the goddess holds a keyboard while benevolently showering her devotees with the ultimate blessing: the elusive $\mathrm{H}-1 \mathrm{~B}$ visa...She leads her followers smoothly through the long process, influencing the minds of visa officers and showing dreams of a better life."

In fact, the painting is more interesting than its description suggests (Figure 1). A thick-fingered, unsmiling goddess stands on the head of an open-mouthed, balding man with sharp teeth and stricken eyes; the keyboard in one of her many clawed hands is brandished as a weapon. There is no benevolence. The reds, blues, and whites of the painting invoke the American dream, but only by revealing its nightmarish cognates. The ground is littered with voided visa applications. The clouds above are stormy. Embedded in this painting's somber elaboration of visa dreams denied is Gawarikar's own experience of moving to the United States from Pune, India, as a "dependent nonimmigrant" spouse on an H-4 visa, one who could neither work nor sell her artwork.

The only thing worse than a visa denied, the painting seems to say, is a visa granted.

This essay is about the Smithsonian's Indian American Heritage Project (IAHP), and how the curatorial practices of its cornerstone exhibit, Beyond Bollywood: Indian Americans Shape the Nation (2014-2015), registered the rhetoric of India's global rise, or, in popular parlance, the emergence of New India. ${ }^{1}$ The rearrangement of territorial attachments, political orientations, and communication technologies referred to under the rubric of "globalization" has also meant a shift in the dominant civilizational assumptions of the 20 ${ }^{\text {th }}$ century, most notably Francis Fukuyama's (1992) idea of "the end of history." This often-troped avowal has now given way to an equally ideological discourse on the "Asian century," which includes New India in its ambit. But whereas the discourse on the rise of China has been bolstered by the statistical inevitability of that nation surpassing the United States as an economic superpower, the narrative of India's rise has been reduced to just that--a narrative, what Susan Stewart terms "a structure of desire" (ix)--whether read as a rhetorical smokescreen for domestic policy

${ }^{1}$ Beyond Bollywood was organized by the Smithsonian's Asian Pacific American Center (APAC) under the auspices of its Indian American Heritage Project (IAHP), which also includes public programs, a school curriculum, an interactive website, and a virtual exhibit. The exhibit opened in February 2014 to considerable fanfare; President Barack Obama congratulated IAHP in an official Presidential missive for "call[ing] on us to recognize ourselves in one another." 


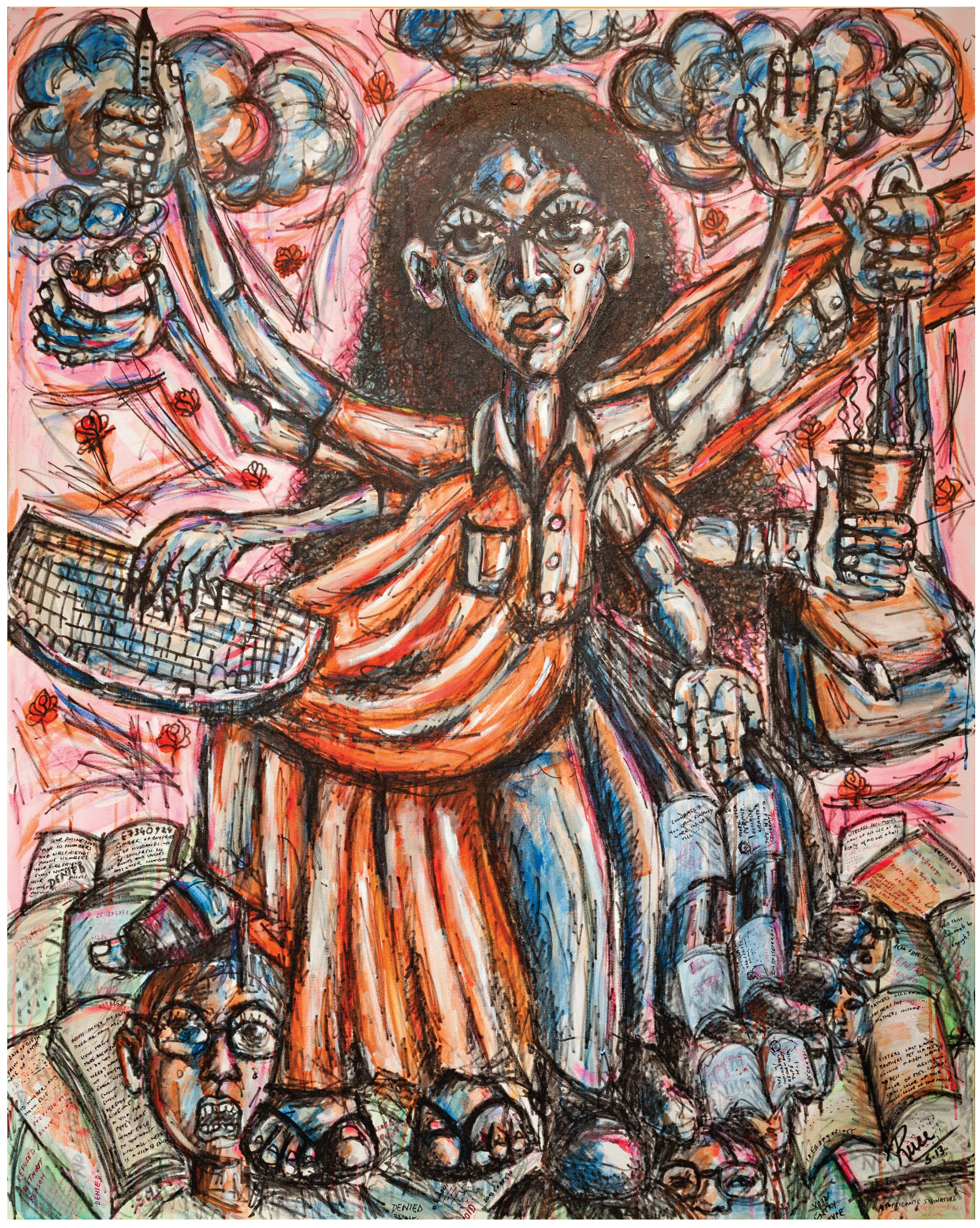

Figure 1. Ruee Gawarikar, The Goddess of Visas, 2013. Mixed media on canvas.

Photograph by James Di Loreto. Courtesy of the Smithsonian Institution. 
failure or an aspirational rallying cry for the new global middle class. The narrative of New India is both an Indian nationalist discourse of global ascension, one which had an earlier incarnation in the right-wing Bharatiya Janata Party's 2004 "India Shining" campaign, as well as an ambivalent discourse that U.S.-based Non-Resident Indians (NRIs) have alternately produced, internalized, and parroted, with varying degrees of intentionality.

When Gawarikar moved to the United States in 2004, she was by one account traveling against the return traffic of Indian Americans to India. As Indians in India increasingly chafed against the imperative of humbling themselves before the Goddess of Visas, significant numbers of Indians in the United States were "going home to bootstrap the economy and reestablish cultural roots" (Heenan, 90), in response to both American economic decline and Asia's global rise. The migrant subject who had left India for America in the name of opportunity now found herself on the wrong side of a history that had not, pace Fukuyama, come to an end. In Shoba Naryan's words, "the East was the new West" (130). Although imperatives of "return" had always characterized diasporic structures of feeling and modes of living, return now took the form of physical reverse migration, compelling increased focus on diasporic reterritorialization in migration studies, sociology, economics, and cultural studies (Markowitz and Steffanson 2004; Tsuda 2009; Hirsch and Miller 2011; Xiang, Yeoh, and Toyota 2013).

At the same time, NRIs who had become hyphenated Indian-Americans in the second-half of the $20^{\text {th }}$ century, many of them naturalized citizens with American-born children and grandchildren, were engaged in unprecedented political mobilization as an increasingly powerful minority constituency in the United States. Wealthy Indians like Kamil Hasan became bundlers for political candidates; others like Ami Bera stood for Congressional office and were elected. A muscular Indian American lobby pushed for what would become the Indo-U.S. Nuclear Agreement, and a handful of selfdescribed Indian American "political operatives" lay the groundwork for a historical initiative at the Smithsonian that would demonstrate that the community's contributions to the United States far predated those evidenced by the present moment, indeed could be traced back to an Indian sailor on a British trading vessel that landed in Massachusetts in 1790.

As Colleen Lye (2015) has recently observed, "the contradictory 'rise of Asia'" affords a new opportunity for the theorization of Asian American racialization, cultural politics, and expressive relations. Immigrant populations have for decades been memorialized in the halls of the Smithsonian, but the historical implications of this form of recognition have shifted along with the globalization of media and the waning of Euro-American hegemony in arguably all but the military-industrial sphere. This essay considers how the discourse on India's arrival onto the global stage raised the critical stakes and possibilities of representing Indian American experiences and subjectivities in the United States in the early 21" century. Global India is with both dozens of billionaires and hundreds of millions in poverty, where the death toll of suiciding famers in Maharashtra alone amounts to an average of ten per day, and a single corporation, the Tatas, runs over a hundred companies (Roy 2014). What do these

\footnotetext{
${ }^{2}$ In 2007, APAC enlisted Parag Mehta, Toby Chaudhuri, and Gautam Raghavan as volunteers for the initiative that would become IAHP. Mehta was then working for the Democratic National Committee; Chaudhuri was Al Gore's former press secretary, and Raghavan was a prominent fundraiser for the DNC.
} 
contradictions, which undergird the narrative of India's rise, have to do with the curation and display of an exhibit on the Indian American community? I read Beyond Bollywood as an exhibit "beside itself," one that extends laterally to register diasporic ambivalence about New India even as it purports to offer a story about Indian American contributions to the project of U.S. national imagining.

Beyond Bollywood is a "multi-modal" exhibit sited in the official-national Smithsonian museum complex. The term "multi-modal" is curator Masum Momaya's (2014) technical description of the collection of artifacts, profiles, photographs, archival documents, and artworks that is intended to illustrate, in her words, the "multidirectional relationship between communities and nation." The language of "multidirectionality" suggests that influence cuts all ways; ethnic communities learn from and contribute to normative national ones, and vice versa. This is an avowal of a lateral, or side-by-side relation, as opposed to a vertical or top-down one, in which communities are overdetermined by nations and wholly subject to their identitarian claims. How did this curatorial vision inflect the narratives that Beyond Bollywood offers about the United States and its communities, and, by that same token, the Indian American community and its multiple national affiliations?

Amit Chaudhuri has recently suggested that globalization is a "text... a fabric of lateral connections and intersections that abhors, and negates, verticality;" it operates through the reinvention of narrativity, transforming the conditions of possibility for storytelling in a world in which there is no longer any "outside" (197-201). Momaya's vision for Beyond Bollywood hews to this contemporary understanding of spatiotemporal relations under the conditions of globalization (i.e., we are all always-alreadyconnected), but it also returns us to older arguments about the nation and its narration (Anderson 1983; Bhabha 1990). This familiar discourse has fallen out of fashion given the popularity of non-national, transnational, and cosmopolitan rubrics in cultural studies, but it is worth revisiting, given that diasporic texts like Beyond Bollywood evidence both the tenacity of nation-orientated thinking in the production of global narratives and the interruptive presence of the global that always inheres in articulations of the nation form.

After the linguistic turn, many theorists argued that the nation is a form of textual affiliation in the process of being narrated, of coming into being in and as language. In Benedict Anderson's canonical argument, it became possible to imagine the nation because of a modern conception of space-time predicated on the primacy of lateral thinking. It was not that past and future collapsed into an instantaneous present, but rather that modernity entailed an expanded notion of the present through the conception of the "meanwhile": "simultaneity [became], as it were, transverse, crosstime" (Anderson, 24). The newspaper and the novel were key technologies vested with, and productive of, this critical "meanwhile": fellow citizen-subjects shared in the "steady, anonymous, simultaneous activity" of reading and took solace in the knowledge of their temporal coincidence and spatial juxtaposition (26). The laterality of the "meanwhile" enabled the development of the "community in anonymity which is the hallmark of modern nations" (36).

In the past three decades, Anderson's argument, which reads anti-colonial nationalisms as derivative of earlier "modular" forms of European and American nationalism, has been the subject of much revision, especially in Postcolonial Studies (Chatterjee 1993). Writing in 1990, Homi Bhabha complicated the notion of simultaneous narration's "meanwhile" by arguing that there are two distinct temporalities of "writing the nation": the pedagogical, in which the nation's people are 
understood as historical objects, and the performative, in which the nation's people are understood as present producers of the national collectivity. This splitting of the national subject is fundamentally ambivalent; the nation speaks a "disjunctive narrative" (311) that lays bare the ways in which modernity has always been constituted through internal contradiction. Following Anderson, Beyond Bollywood's "multidirectional" multi-modality is the enabling condition of the exhibit's Janus-faced narrative posture, its ability to simultaneously tell an Indian story and an American one. Following Bhabha, the curatorial assumption of lateral relation is responsible for the exhibit's critical registration of the "doubts and unease" (Parry, 11) of American imperial hegemony, on the one hand, and New Indian globalism, on the other. The exhibit's displays are split between the pedagogical time of its artifacts--material cultural objects intended to articulate the Indian American community into the U.S. national subject--and the performative time of its artworks, which reckon with India's rise.

If the narrative of India's rise has been contradictory (it celebrates Indian billionaires while lingering "behind the Beautiful Forevers" [Boo 2012]), so, too, is Beyond Bollywood undergirded by a set of discursive contradictions, evidenced by the accounts given by its organizers. During Beyond Bollywood's fundraising campaign, APAC director Konrad Ng (2013) repeatedly told press, "The Indian American story has yet to be fully told." In fact, versions of "the Indian American story" have been told for decades, from the ambassadorial writings of India-born, U.S.-based writers Dhan Gopal Mukherji (1923) and Santha Rama Rau (Burton 2007), to the hefty archives of the Indian American ethnic media since the 1970 founding of India Abroad. ${ }^{\text {In }}$ a similar vein, founding curator Pawan Dhingra told the press: "Though immigrants from India came to America as early as the $18^{ }$Century, Indian Americans are still an emerging community" (HomeSpun 2011).

Both Ng's and Dhingra's statements demand that we put pressure on the language of "emergence." Immigrant populations frequently stake their identitarian claims to the "host" country on the perception of mainstream acceptance, and the story of the Indian American community has exemplarily been one of repeat emergence, whether in terms of literary and media events (e.g. the film Gandhi, 1982; Jhumpa Lahiri's 1999 Pulitzer for The Interpreter of Maladies), bilateral Indo-U.S. initiatives (e.g. the 123 Agreement of 2008), or high profile individual achievements (e.g. Sabeer Bhatia's founding of Hotmail, 1996; Satya Nadella's ascension to Microsoft CEO, 2014). The insistence on narrative beginning--on having arrived, on telling a story for the first time--serves "to modify the meaning of past occurrences after the event...by refuting a first interpretation and replacing it with a new one" (Genette, 56). In each instance, India is said to have finally "arrived" into the collective American consciousness.

Both the discourse of Indian American arrival and the narrative of India's rise are about a dawning into heightened visibility, a coming into view; each is a rhetorical strategy intended to vitiate earlier narratives of emergence and to retrain the public's eye on the community, issue, or situation of the moment in question. Consider Beyond Bollywood's unofficial motto: "It's time to tell the Indian American story." The implication is that it's finally time (that we've been waiting for); it's time now (when it

\footnotetext{
${ }^{3}$ The Indian American story has been delivered in similar meta-narrative form by the South Asian American Digital Archive, the Ghadar Memorial, library collections including that of the Bancroft Museum at the University of California, Berkeley, and institutions like the Indo-American Heritage Museum in Chicago, IL.
} 
hasn't been before). That history contradicts this claim does nothing to lesson its force as an organizing charge, and the radical presentism of the exhibit's meta-narrative complicates the diasporic tendency for nostalgia, the seeking of authenticity elsewhere, back there, before, not here. The time of the collection is now. The time of the Indian American community throughout history is made "simultaneous" (Stewart, 151) by the realities of traversing continuous museum space. In less than an hour, the museum visitor walks from 1790 to 2014. The stories of Kanta Chandra, who fought for six decades to obtain U.S. citizenship after her arrival in California in 1910, and New Yorkbased fashionista Naeem Khan, who designed a dress for First Lady Michelle Obama in 2009 , reside on a plane of spacio-temporal synchronicity.

Beyond Bollywood: Indian Americans Shape the Nation is sited at the NMNH, but, as I will show, it repeatedly cites India. The "nation" to which the subtitle refers is thus at once the United States and India. The exhibit sheds light on its Indian American subjects' ideologically mediated relations to the complexes of American citizenship, nationhood, diasporic belonging, and liberal multiculturalism, but it also does something more in registering the pressures of India's rise. While the displayed artifacts narrate the story of the Indian community in the United States in a pedagogical mode, nearby artworks performatively sound the rise of New India. In short, the exhibit unfolds "contrapuntally," in Edward Said's terms, evidencing a "plurality of vision [that] gives rise to an awareness of simultaneous dimensions" (186). Said's notion of the contrapuntal affords us a term in which to couch our revision of Bhabha's theory of performative disjunction. The exhibit not only captures the ambivalence of Indian American diasporic lived experience, but also the futility of the attempt to domesticate India as a relic of the American immigrant's "past" in the era of New Indian futurity.

While the story of India's rise might violate the law of non-contradiction in analytical terms--its stark poverty a ready counter to blanket claims of economic growth--it nevertheless speaks to a discursive truth, which makes salient the distinction between the concept of contradiction and the experience of it, or the fact that something can be a contradiction in a "genuine or true way" (Ricciardone 2014). In what follows, I focus first on the curatorial principles of collection involved in assembling the exhibit, and second on the heightened contradictoriness of the display itself: the dueling narratives put forth by its artifacts on the one hand and artworks on the other. I seek to make two related arguments. Drawing a distinction between those objects displayed in Beyond Bollywood and those collected by the Smithsonian's National Museum of American History (NMAH), I argue that the discourse of India's rise complicates the standard logics of multiculturalism at work in the Smithsonian's museums--or, to make a more modest claim, our readings of them. Second, I distinguish between the contrapuntal narratives of the artifacts and artworks, showing how global India interrupts the exhibit's pedagogical address to both its Indian American and normative American audiences.

By focusing on the relation between political and aesthetic modes of representation in the exhibit, I show that what Bhabha reads as a narrative splitting of the nation into pedagogical object and performative subject can actually refer to a doubling into two independent narratives. The difference between narrative splitting

\footnotetext{
${ }^{4}$ Following the conventions established by earlier APAC exhibits, like "From Bento to Mixed Plate: Americans of Japanese Ancestry in Multicultural Hawai'I" (1999) and "Exit Saigon, Enter Little Saigon: Vietnamese America since 1975" (2007), Beyond Bollywood focuses on the themes of "challenges, contributions, and change."
} 
and narrative doubling is the difference between split-subjectivity and double consciousness, or fragmentation and duality. It is the difference between division and multiplication, a difference that must be rigorously specified if we are to understand the dynamic operations of New India's contradictions as a force, not of negation, but of the creation of plural truths.

\section{Principles of Collection and Selection}

Communal narratives, artifacts, and luminaries merit collection and display for a number of reasons, the foremost being that, in John L. Jackson's succinct formulation, "identities rely on archives" (11; see also Bal 1994; Clifford 1988). If we are to know who we are in the present, we have to be able to say who we were in the past to those who succeed us in the future. We have to be able to see, touch, examine, and hear the things we made in order to give legitimacy to our ancestral claims and have a basis for the articulation of collective aspirations. But communities are not things. They are "experienced as encounters" (Karp, 4) and cannot be reduced to the artifacts that are asked to serve in metaphoric and metonymic relation to their owners and producers. On what terms, then, is any community displayed--not its art or culture, not its material artifice, but the community itself? What curatorial principle is adequate to the challenge?

A curator is not simply someone who selects what will appear in a collection--not a mere agent of "enlightened sampling" (Schlatter, 54)--but rather a caretaker of objects, a creator of value, and an agent of canonization. Curators play a mediating role between artists/object-owners and the audiences to whom their eventual exhibits are addressed. Curators are also representatives of institutions, and, to that end, authorized wielders of a particular institution's symbolic power and cultural capital. The curator determines what is chosen for display--determines and enacts the principles of selection--but is not the only value creator. An exhibit derives its particular force from the "white cube" in which it's housed, and Beyond Bollywood is a prime example. Like the newspaper of record, the New York Times, the Smithsonian has brand-name recognition as the United States' official historical archive. To be in the Smithsonian is to be accorded a place in the national memory, to have been written into the American story. Thus when Beyond Bollywood opened, the Indian American community could celebrate having planted its flag at the Smithsonian (Kurin 2014).

\section{Principles of Collection}

What is the relationship between the "collective"--which describes in its adjectival form that which a number of individuals hold "in common" and in its noun form the group constituted by the individuals in question (its dual definitions speak to the relation between having a thing and being that thing [Brown, 13])--and the "collection," which we might understand as "objects generated by means of narrative" (Stewart, xii; Bal 1994)? As I have been suggesting, Beyond Bollywood is a collection generated by means of the interplay of two narratives: Indian American emergence and India's global rise. It is also, as organizers and curators have consistently emphasized, a self-named act of collective self-representation: "This is not an Indian American story brought to you by some other entity; it's by the community itself" (Dhingra 2014).

If autobiography is a genre in which "the artist and the model coincide, the historian tackles himself as object" (Gusdorf, 31), and autoethnography can be 
understood as a practice of engagement with how you've been represented by others (Pratt 1991), then how are we to understand a collective collection "by the community itself"? "To collect" is "to gather," "to get together," a group of things which are intended to be "viewed as a whole" (OED 2014). Definitionally, then, the museum exhibit is an assemblage of objects by, from, and representing a group of individuals who tacitly or explicitly hold these objects in common--because, in fact, they are their objects--and seek to enable their holistic viewing. The desire to be one's own object is the desire for adequate, authentic representation of the self, but in Barbara KirshenblattGimblett's words, "self-representation is representation nonetheless" (416). In Beyond Bollywood, the curatorial challenge of constructing a meta-narrative about a diverse community remained, despite the involvement of Indian Americans around the United States who were crowd-sourced for contributions of shoes and family photographs (Figure 2).

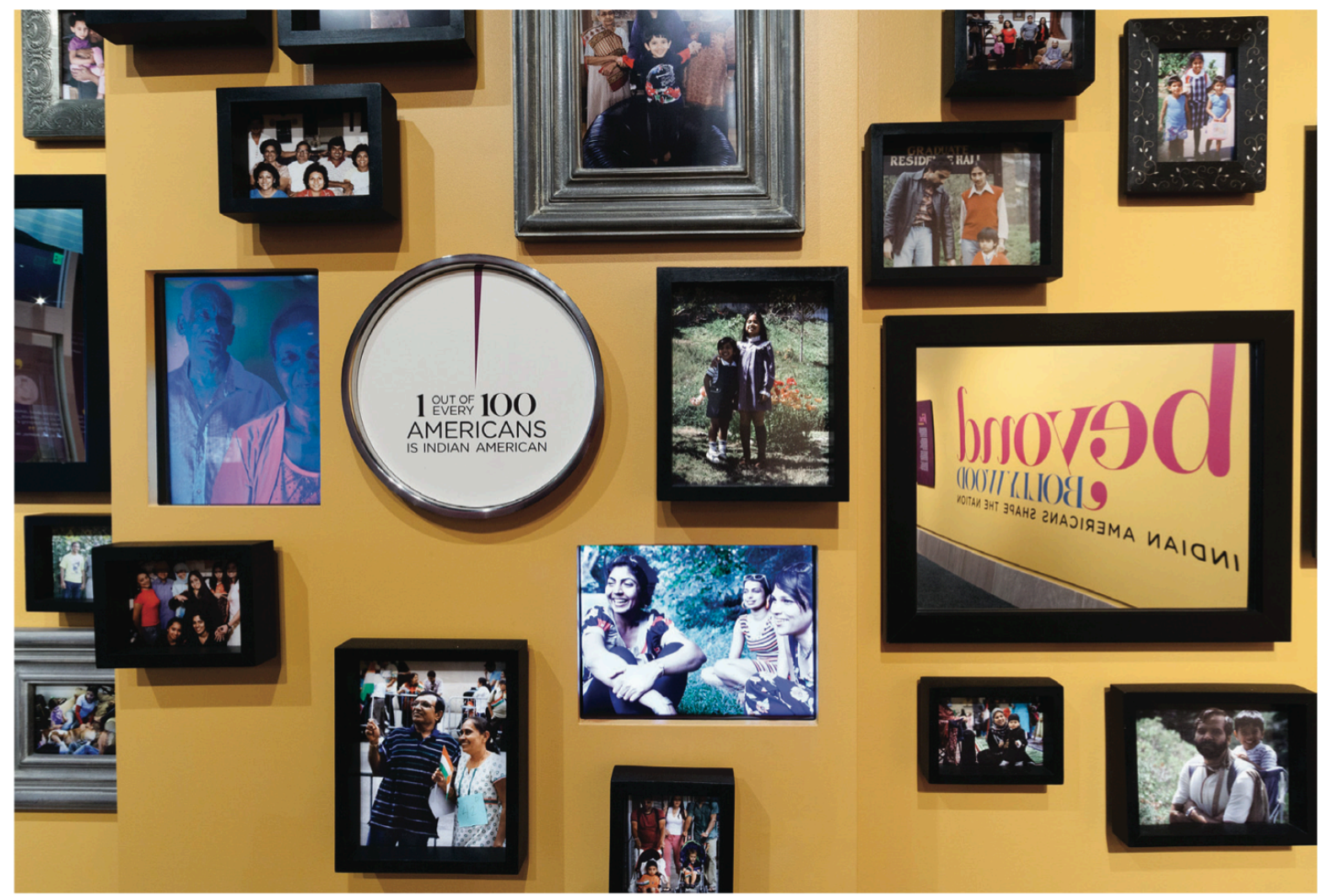

Figure 2. The opening gallery of Beyond Bollywood: Indian Americans Shape the Nation features a wall of family photos with this descriptive display text: " 1 out of every 100 Americans is Indian American." Photograph by Donald E. Hurlbert. Courtesy of the Smithsonian Institution.

Curatorial crowd-sourcing may have created feelings of investment on the part of participating contributors, but that does not mean it transformed the authorial voice 
of the exhibit into a "collective" one. ${ }^{5}$ Like a literary anthology and the editorial principles operative in its constitution, exhibits evidence the individual tastes and institutional imperatives that inform curatorial selection. In addition, both anthology and exhibit can be understood as intertextual fields of fragments, which are subject to the fundamental principle of the modernist aesthetic: "the impossibility of representing totality" (Chaudhuri, 144). Failure is also a characteristic of the collection in Stewart's account: the non-representational collection is neither a proxy for nor a portrait of the world it names, but rather "a hermetic world... an autonomous world...singular" (152). A collection has greatest value when it contains a finite set of some objects (e.g. all the tea kettles) or unique objects (e.g. the Hope diamond) in the world. However, even as an autonomous world the collection maintains a relation to the other-world in which it exists, and it is this relation of externality that generates its imaginary. To be sure, Beyond Bollywood is the result of the curator's narrative predilections, but the exhibit nevertheless aspires to represent a collectivity through the acquisition and display of historically significant objects and artifacts.

Thus far, I have used the language of "display" and "collection" without accounting for the distinction. Here, I want to stress the distinction between being seen in (displayed) and being acquired by (collected) the Smithsonian. By its own tally, the Smithsonian has over 137 million objects in its permanent collections, but in 2007, when IAHP got under way, there was reportedly nothing representing the 3.3 million people of Indian origin in the United States. Every collection begins with "initial blindness--by visual lack" (Bal, 88), and IAHP declared Indian American absence from the collection as the impetus for Beyond Bollywood. I want to put pressure on this originary claim, for it hinges on the distinction between the Smithsonian's permanent collections and its official archive. The former houses quantifiable "artifacts, works of art, and specimens"; the latter holds "materials" which, as the Smithsonian's website declares, occupy 136,194 cubic feet of space. An archive "designates a territory and not a particular narrative," and unlike a collection has no imperative to "exhibit, display, or interpret its holdings" (Cummings and Lewandowska, 149).

The Smithsonian's archive (now, as in 2007) actually contains numerous images from India and of Indians, as well as records from India-focused exhibitions throughout the institution's history, like the 1985-6 Festival of India. There are images of Indian Americans like Kehar Singh Chouké, who came to the United States in 1917 and taught medicine at schools around the country, and astronomer Subrahmanyan Chandrasekhar of the University of Chicago, who was awarded the 1983 Nobel Prize in physics. Whether or not these archival texts constitute adequate representation, the fact is that the rhetoric of invisibility was marshaled in support of an exhibit that was then framed as a corrective to a gap that was never precisely specified to donors, contributors, and volunteers, who understood themselves to be, in IAHP volunteer Parag Mehta's (2014) words, "start[ing] a long overdue conversation," as opposed to participating in one that had long since been underway.

\footnotetext{
5 "Indian Americans: Who are WE?" the opening panel asks. The exhibit defines its subjects as "students, farmers, physicians, artists, cab drivers, businesspeople, and technology pioneers," as well as "entrepreneurs...public servants, and organizers for civil rights," spelling bee winners, chefs, writers, and, in the highlighted words of (American) football player, Brandon Chillar, "some BIG DUDES too." The list is inclusive both of the working class and the elite, children and adults, activists and athletes, but the objects selected for the Smithsonian's permanent collections--including artifacts of Congressman Saund and entrepreneur Vinod Dham--are more limited in scope, suggesting a normative American masculinism at work in the area of acquisitions.
} 
In my discussion with Dhingra, he used the language of collections and archive interchangeably; he stressed that enriching the Smithsonian archive had been one of his primary curatorial goals and would "[have] value beyond an exhibition that's up for a year" (2014). The gap to which Beyond Bollywood's curators referred was not a gap in the archive--not an absence from historical documentation as such--but an absence of objects, things, the material stuff of Indian American lives. The implication was that material artifacts were needed to give form and force to an existent narrative of Indian American presence that would otherwise be deemed insufficient; that narrative required the testimony of the object to corroborate, bear witness to, and concretize its claims of arrival, contribution, negotiation, and change. But APAC is not an authorized collecting unit of the Smithsonian, and IAHP was technically only charged with displaying objects, not collecting them. From the outset, then, the curators were limited in their abilities to rectify this constitutive lack of things.

Today, there is the exhibition itself, on display in a 5,000 square foot gallery, and then there are the items that were acquired for the Smithonian's permanent collection through IAHP efforts during the process of curating Beyond Bollywood. In other words, there are those objects deemed appropriate for display under the sign of "Beyond Bollywood," and then those deemed worthy of catalogued acquisition and preservation by the Smithsonian under the sign of "American History." The latter include campaign materials of the first Indian, Asian, and Sikh American Congressman, Dalip Singh Saund (his books Congressman from India [1960] and What America Means to Me [1952], as well as a collection of bumper stickers); a plaque honoring Vinod Dham as founder of the Intel 486 Pentium chip; the turban of Balbir Singh Sodhi; a New York City taxi meter, ca. 1980; and a CB Radio. ${ }^{6}$ Unlike the other displayed objects, these select few will be available for curation as part of future exhibits and programs. They now exist simultaneously in two collections of distinct value: on the one hand, the collection that is Beyond Bollywood, and, on the other, the permanent collection of the NMAH, which includes handbills from the 1963 March on Washington and baseballs autographed by Babe Ruth.

The American History Museum's permanent collection effects a kind of canonization that is withheld from most of the objects on display in Beyond Bollywood: among them Abraham Verghese's doctor bag, Balu Natarajan's spelling bee trophy, Mohini Bharadwaj's Olympic medal, and Brandon Chillar's football helmet. In some cases, this is because the object in question was offered by its owner "on loan" and was never available for acquisition by the Smithsonian. In the case of Verghese, however, the object was gifted by its owner to APAC, but was not selected for the museum's collections.' One might argue that the work of all ethnic representational texts and sites is to bring a people, their labor, and their material artifice to the attention of a wider collectivity, and in so doing to elevate the products of their life to the status of the

${ }^{6}$ A number of artifacts have been acquired by the Archives Center at the NMAH from the South Asian Lesbian and Gay Association, including fliers, newsletters, and posters. When I asked Momaya for a list of artifacts acquired under the auspices of Beyond Bollywood, she did not include these items.

${ }^{7}$ In an email exchange on May 5, 2014, Momaya said that APAC may pursue acquisition of Verghese's doctor bag by the NMAH after Beyond Bollywood closes. Otherwise, Momaya said in a July 3 , 2014, email exchange, when the exhibit finishes touring the country in 2019, the doctor bag, along with the display panels and text of the exhibit, might be "stored, donated or destroyed. All those options are still on the table." In the case of included artworks, like Gawarikar's "The Goddess of Visas," the issue of collection was never discussed. "I would of course offer if they ask," Gawarikar told me, "but I don't think they are interested" (2014). 
collection-worthy, valued, and seen. But if, as Dhingra suggests, the historically significant outcome of Beyond Bollywood is that certain objects have been collected under the sign of "American History," then the limited number of acquisitions suggests the limits of the Smithsonian's politics of inclusion, and the Indian American community's declaration of arrival into the Nation's Attic belies the tenacity of a multicultural logic that would put the community on display but not canonize its works.

\section{Principles of Selection}

Strictly speaking, Dhingra and Momaya practiced selection, not collection, as curators for a non-collecting body. Who and what did they select to represent Indian Americans, and is there a pattern to who and what is missing?

The most prominent individual featured is Dalip Singh Saund, the first Asian American Congressman, pictured with then-Senators John F. Kennedy and Lyndon B. Johnson on an entire gallery wall. On another imposing wall, the names of unknown Indian Americans are provided in attribution to quotations about religious life in the United States, young Zoroastrians, Muslims, Hindus, Christians, and Jains who are allotted more of the exhibit's coveted real estate than many celebrity NRIs. Indeed, some of the most famous American desis are missing altogether: writers Anita Desai, Kiran Desai, and Chitra Banerjee Divakaruni, journalist Fareed Zakaria, Sun Microsystems co-founder Vinod Khosla, self-help guru Deepak Chopra, and Top Chef's Padma Lakshmi, among others. The exhibit declines to claim novelist Salman Rushdie, who has for many years resided in New York, while featuring others born outside of the United States, like filmmaker M. Night Shyamalan.

Highlighted individuals are Indian Americans by virtue of immigration or birth; highlighted phenomena are Indian by virtue of origin or association. A section on "Ground breakers" profiles pioneers in different fields, their thali-framed portraits affixed on the gallery walls. These range from literature (Bharati Mukherjee) to sports (e.g. tennis player Rajeev Ram) to film and media (e.g. Shyamalan and television star Mindy Kaling) and science (e.g. Nobel-winning biochemist Har Gobind Khorana). The individuals are "firsts" in their respective domains, which is why, for example, Mukherjee is listed and not the better-known writer, Jhumpa Lahiri. The gravity of inclusion is distributed equally amongst veritable luminaries and the comparatively unknown. It grants space to people and professions not typically associated with Indian Americans (basketball, not business; fashion design, not internal medicine), but it also reduces each of the "Ground breakers" to a representative instance of his or her professionalized ethnicity.

Contemporary politicians including Governors Bobby Jindal of Louisiana and Nikki Haley of South Carolina are omitted entirely, as Smithsonian regulations guard against the perception of political endorsement. This is an ironic omission, both because of the support the exhibit has garnered from politicians like Congressman Bera of Sacramento County, California, and because the ethnic collective is foremost a political community. In my conversations with them, Dhingra, Mehta, and Momaya all emphasized Beyond Bollywood's political force. Mehta said that the exhibit was framed as "a truly American story" in order to "give the credit back to the country." Dhingra noted: "Once we become part of the cultural mainstream, it makes our [political, professional, and legacy] ambitions easier."

This explains why Beyond Bollywood values incidents over organizations, and media-worthy spectacles over sustained efforts: The exhibit seeks to demonstrate the 
Indian American community's legibility in terms of normative American identitarian formations. It consequently highlights figures and phenomena that are assumed to have impacted or symbolically resonate with non-Indian Americans: football players, Weight Watchers, yoga. In this narrative, Nina Davuluri, the first Indian American Miss America, becomes the apotheosis of nation-shaping, but there is no space for the outlets and institutions that explicitly serve the Indian American community, whether nongovernmental organizations like the America India Foundation, or the India Community Center in Milpitas, California, which is the largest Indian American community organization in North America.

The omission of one artifact particularly impoverishes the exhibit's narrative: a 1997 flier announcing a South Asian Lesbian and Gay Association (SALGA) community education panel addressing the Federation of Indian Association's (FIA) refusal to allow SALGA to participate in that year's India Day Parade. The flier was acquired by the NMAH in 2011 through Dhingra's efforts, and the explanatory text panel would have had to identify it as belonging to the "Archives Center at the National Museum of American History." The flier would have contextualized the activism leading up to the FIA's inclusion of SALGA in its 2000 parade, which the exhibit shows through a displayed photograph, as well as provide the opportunity for viewers to encounter it as a piece of American History. Instead, the intra-communal milestone is relegated to a strip of wall easily missed between a section on hip-hop and an installation of a kitchen table. The opportunity to acknowledge South Asian gender activism as a species of a larger American social movement is missed, and the question of a South Asian organization's (SALGA) relation to a nominally Indian one (FIA) is elided altogether (Srinivasan 2014).

The marginalization of SALGA is less surprising if we consider the multicultural logic at work in Beyond Bollywood. Although multiculturalism's politics of recognition is by now over-familiar, the tenacity of its logic under the conditions of globalization bears further scrutiny. As Sneja Gunew writes, multiculturalism tends to be "an embarrassing term to invoke partly because it [is] perceived as automatically aligned with and hopelessly co-opted by the state," and yet it is increasingly "a global discourse since it takes into account the dynamics of diasporas and their relations with nation states and other entities" (15). In the next section, I want to think about the content of Indian American collective "ambitions" and propose that we read the displayed objects and artifacts as operating on the "pedagogical time" of U.S. multiculturalism. On what grounds does a community attempt to write itself into the cultural mainstream? What was multiculturalism supposed to teach us, over and above what it purported to protect?

\section{Pedagogical Time: Multiculturalism's Subject Lessons}

Diversity has always been sound business (Lowe 1996). If the list of "Ground breakers" discussed above sounds familiar, it is because we have seen the extended logic of liberal multiculturalism at work in this way before, most tellingly in the many faces of an American icon who has also appeared, in various accessorized incarnations, as tennis player, astronaut, and movie star: Barbie. Barbie is that highly gendered American female subject who can "do anything" and "be anybody," or so the story goes. Tellingly, Mattel didn't succeed in selling Barbie dolls in India until it dressed "a white "American' Barbie" in a sari, mediating both race and nationality through "ethnic" costume (Grewal, 96). 
Beyond Bollywood's "Ground breakers" are like Barbie in this way: Barbie is a white American who can be anything (according to the ideology of the American dream) and "look like" anyone; the "Ground breakers" are ethnic Indian Americans who can be anything, but always only appear as themselves, i.e., as ethnic subjects. In both cases, the subject to be celebrated is the United States, which has supposedly enabled its gendered and ethnic minorities to climb the proverbial ladders, crash through the (glass or bamboo) ceilings, and break ground in their pursuits of economic success and societal recognition. In Mehta's (2014) description of Beyond Bollywood's rhetorical posture, "We don't [say], 'look how successful [Indian Americans] are...We say we've done all these things because of the largesse of the American people."

The "Ground breakers" wall repeats a common convention in American ethnic representation: on the one hand, it transposes narratives of individual success into occasions for communal celebration and recognition by others; on the other hand, it creates an opportunity to articulate the (grateful) community into the nation. The "ground" being broken is that of the so-called mainstream; it is a metaphoric inversion of the glass ceiling that similarly valorizes what the exhibit's explanatory text calls the "spectacular achievement" of an exceptional few. If Barbie's appearance in multiple professional modes actually reinforces the fact that she promotes "a very limited set of products, ideas, and actions" (Grewal, 100), then the Indian American subject's appearance as writer-athlete-model serves to reinforce dominant structures of valuation (the Pulitzer, the Olympics, the NCAA), and Barbie's ability to take on or off her ethnic costume puts into relief the Indian American ethnic subject's comparative inability to "pass."

In The Protestant Ethnic and the Spirit of Capitalism (2002), Rey Chow argues that ethnic self-production under capitalism operates through "coercive mimeticism": the imperative to produce a prescribed image of the self as other. The organizing conceit of Chow's text is a reading, via Max Weber's The Protestant Ethic and the Spirit of Capitalism (1905), of the ethnic as one who "protests." Weber attributes the spirit of capitalism to the pervasive belief in the secularizing West that "one is divinely endowed with a life task, a mission, or a field to which one is supposed to devote one's best energies" (Chow 2002, 43). Chow locates this same mode of "internal disciplining" in contemporary articulations of ethnicity. Her argument also follows from Michel Foucault's well-known repressive hypothesis in The History of Sexuality (1978). Arguing that sexuality, race, and ethnicity are similarly constitutive identity categories, Chow wages what we may term a critique of the oppressive hypothesis, arguing that the marginalization of the ethnic subject not only creates the imperative of self-production but also generates discourses of multicultural inclusion.

Chow's argument has been incredibly influential in cultural studies of identity (see Gunew 2013; Viego 2007), but its almost airtight repudiation of the possibility of ethnic self-expression that does not render that subject abject risks closing down the inquiry into ethnic cultural production, as opposed to opening up new lines of inquiry. The critique of multicultural inclusion is also now so routinized that it is easy to forget that multiculturalism was once imagined as a radical philosophical program. In a memorable argument, Charles Taylor showed that multiculturalism understands identity as a "fundamental defining characteristic" of a person, the recognition of which is "a vital human need" (25-26). It holds as axiomatic that "people can suffer real damage, real distortion, if the people or society around them mirror back to them a confining or demeaning or contemptible picture of themselves" (25). To wit, multiculturalism importantly acknowledges that nonrecognition and misrecognition are 
forms of oppression with ontological repercussions; this, of course, is an argument made famous in a different idiom by Frantz Fanon.

Whereas, for Chow, ethnic self-representation is a form of coercive mimeticism resulting in abjection, Taylor locates the imperatives of minority self-production in the

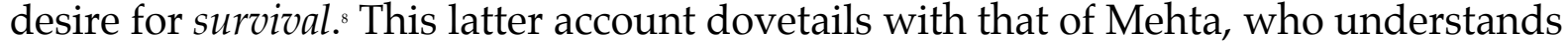
the exhibit as part of a broader political effort to ensure the protection of American minorities: "[Indian Americans] have a responsibility to make ourselves part of the system...to make sure that we are never made the other in our own country" (2014). Beyond Bollywood's stated objective may have been "to tell the Indian American story" (HomeSpun 2011), but, following Taylor and Mehta, I want to suggest that it utilizes five distinct tactics in the service of the goal of communal survival. These are:

1) witnessing: the exhibit documents the history of the community it addresses and calls into being

2) creating community: the exhibit hails different audiences into recognition of themselves as part of the addressed collectivity and/or into practices that will lead to eventual identification with other community members

3) pedagogy: the exhibit teaches both community and non-community members about the community's history, concerns, ambitions, and goals

4) celebration: the exhibit fosters sentiments of self-worth, pride, and investment in the achievements of fellow community members

5) correction: the exhibit counters misrepresentations of the community, especially those trafficked by mainstream media and dominant discourses Each of these goals maps onto a particular aspect of the multicultural politics of inclusion, which I enumerate in what follows.

First is multiculturalism's affordance of representation, not redistribution: The rhetoric of diversity may enable the qualified representation of cultural and ethnic differences in mainstream spheres, but it stops short of the redistribution of material resources (Ferguson 2012). The Smithsonian's allotment of space for the exhibit adheres to this representational logic, and the witnessing, or documentary, displays of the exhibition serve as reminders of the limited number of NMAH acquisitions made in Beyond Bollywood's name. Granted, the number of acquisitions does not necessarily equate to the quality, adequacy, or efficacy of representation; however, Ferguson's insistence on the redistribution of resources is relevant given that Beyond Bollywood was intended as a corrective to a lack of representation in quantitative terms.

Second is the way that multicultural inclusion reinforces exclusion, as in the case of institutions like Black History Month. The specified inclusion of ethnic subjects through such initiatives not only reinforces ongoing exclusions of those same subjects, but also constitutes ethnicity as a category that necessitates special treatment. Beyond Bollywood is clearly the product of the Smithsonian Institution's allotment of floor space for "Indian Americans" alongside exhibits on the masonry of Mali and ancient Egyptian burial practices. On a micro level, each of the exhibit's attempts to define the community it represents also falls into this logic of "tolerance...cathected to advantage" (Chow 2002, 13); a prime example is the marginal representation of SALGA.

\footnotetext{
${ }^{8}$ Responding to Taylor, Kwame Anthony Appiah notes that it's not enough that our culture survives; "we" must be the ones passing it on from generation to generation: "A proposal to solve the problems of Canada by paying a group of unrelated people to carry on French Canadian culture on some island in the South Pacific simply would not meet the need" $(1992,157)$. In other words, it's not cultural artifacts as such that communities seek to see survive; it's themselves.
} 
Third is the conflation of post-colonial and ethnic subjects through the coextensive technologies of racialization and ethnicization. Indians from India and U.S.-born Indian Americans are both considered "minorities" in the United States, "aliens from elsewhere" (Chow 2002,34). The exhibit that strives to instruct its audiences in all things Indian American enacts this conflation as well. A slippage between "India" and "Indian" in America is evident in many of the displayed artifacts, including a 1960s Hills Brothers coffee tin, featuring reductive images of the exotic East and photos of Marilyn Monroe assuming yoga poses for a 1946 fitness ad. By decorating the yoga pavilion with America's favorite pinup, the exhibit conflates India's influences on American popular culture with Indian American contributions to the political and cultural spheres.

Fourth is model minority-ism, the pernicious affective structure whereby select groups, particularly Asian and Indian Americans, are deemed superior to others because they are supposedly better able to seize the opportunities for individual advancement offered by multicultural society. This assignment is often internalized by the "model" groups in question and used by the state in the condemnation of nonmodel groups (Prashad 2000; Lye 2005). Unsurprisingly, model minority mythology is both countered and reinforced in Beyond Bollywood, and it is especially evident in the exhibit's celebratory profiles of individuals like Abraham Verghese. Verghese's doctor bag, which he used in Tennessee in the 1980s, was one of the items offered to but not acquired by the Smithsonian, though it is on display in the exhibit. At the risk of speculation, what threat might the bag have posed to the NMAH, and what would its collection under the sign of "American History" mean today?

The curatorial text panel describes the doctor bag as a symbol of Indian American efforts to find "a foothold in the American Dream": "Many Indian immigrant doctors found their first jobs in rural communities, where life was a stark contrast to bustling India." "Bustling" is the curator's euphemism for an India characterized by overpopulation and scarcity, plentiful solutions and inadequate means for their implementation. In fact, Verghese (1997) has himself described departing India in the years before India' global rise; America was "the very situation [he] had visualized for years," and a contrast not with the "bustling India" Beyond Bollywood names, but rather an India in which "the demands always outstripped the resources" (Verghese, 71). Verghese's migration was underlain with the desire to be better appreciated and to have other opportunities for self-appreciation. The doctor bag thus represents not the achievement of the American dream as such, but rather the poignancy of Indian dreams of America: of an America of resources that would better appreciate India's human resources than India itself.

Finally, similarity returns difference. Normatively American identitarian performances by an ethnic subject--e.g. Davuluri's participation in the Miss America pageant--constitute that subject as "almost the same, but not quite" (Bhabha, 122) as the subject whom her performance approximates. This is clearest in those aspects of the exhibit that are correctives to misrepresentations, mishailings, and misperceptions, especially the turban of Balbir Singh Sodhi, who was murdered in the aftermath of the attacks on the World Trade Center.

9 "Indian Americans [in films are] often typecast as engineers or doctors," one text panel reads, "reinforcing the myth that all are educationally and financially successful." Across the room, another panel boasts, " 1 out of every 10 Indian Americans is a doctor, dentist, nurse, or physical therapist." 
On September 15, 2001, Sodhi was shot outside the gas station he owned in Mesa, Arizona, as he was arranging American flags for the entrance display. The flags were intended to ward off just the manner of hate crime to which Sodhi lost his life. Now, his signature blue turban sits in for his body at the Smithsonian, where it has been acquired for the permanent collection of the NMAH (Figure 3). Sodhi's turban is key to Beyond Bollywood's diasporic imaginary, a formation of "temporality, affect, and corporeality" that generates diasporic subjects (Axel, 411). On the one hand, the turban is a sign of Indian American alterity; it is the mark of Sodhi's ineluctable otherness, the symbol that served as alibi-provocation for his murderous assailant in the days after September 11, 2001. On the other hand, in its glass case with the descriptive textual identification, "National Museum of American History / Gift of the Sodhi Family," the turban can be read as a sign of the dispositional evolution of the American collective consciousness.

Beyond Bollywood specifically cues this latter reading, by juxtaposing the turban with a widely reproduced August 2012 political cartoon, which shows Uncle Sam embracing a red-turbaned Sikh American..$^{10}$ All of us--citizens, immigrants, patriots, and dissidents--want "to give the nation another chance not to betray [our] desire for it" (Berlant, 26), and the visualization of reciprocal embrace in the aftermath of murder attempts to do just that for the Indian American community. Instead of repatriating Sodhi's remains to the India in which he was born, the United States embraces him as a patriot who mistakenly died a suspected terrorist. That this retrospective embrace is contingent upon the continued Indian American performance of difference, a performance that will always render the ethnic subject vulnerable to violence, is left unsaid.

\section{Performative Time: (Art) Object Lessons}

In 2007, Parag Mehta and Toby Chaudhuri had one goal for Beyond Bollywood: It wasn't going to be about India. "It was not [going to be] Holi and Diwali and Rangoli and Hinduism. It was, 'let's tell the story of Indians in the United States, how they got here, where they came from, what they did, and why it mattered" (Mehta 2014).

Yet, in its final incarnation, Beyond Bollywood returns repeatedly to the India from which it professes to depart, right from the words of the opening text panel: "In the western imagination, India conjures up...elephants, saris, and spices...But in America, India's contributions stretch far beyond these stereotypes." This is not necessarily surprising, as distinctions between diasporic narratives and national ones, between Indian culture and its desi derivates, can be thin. What's at stake, however, in the conflation of India's image in the United States with Indian American contributions to the nation is an eclipse of the present, in which India has assumed new prominence on the world stage and diasporic subjects are increasingly returning "home," or

${ }^{10}$ The August 2012 cartoon is by Michael Ramirez, a Pulitzer-winning conservative cartoonist, whose recent work frequently targets the Affordable Healthcare Act, and whose depictions of a Dumboeared, toothy President Obama include portrayals of Obama as a suicide bomber strapped with a "debt"bomb. The exhibit does not provide this information, but it is significant for two reasons: first, because it can be read as illustrating the exhibit's premise that Indian Americans are "shaping the nation" by suggesting the transformation of Ramirez' perspective on American identity; and second, because the acceptance of Indians into the ranks of mainstream American identity must be contextualized alongside the rampant Islamophobia and marginalization of other non-"model" minorities, including African Americans. The exhibit gestures at this conjuncture, but for the most part it is beyond its scope. 


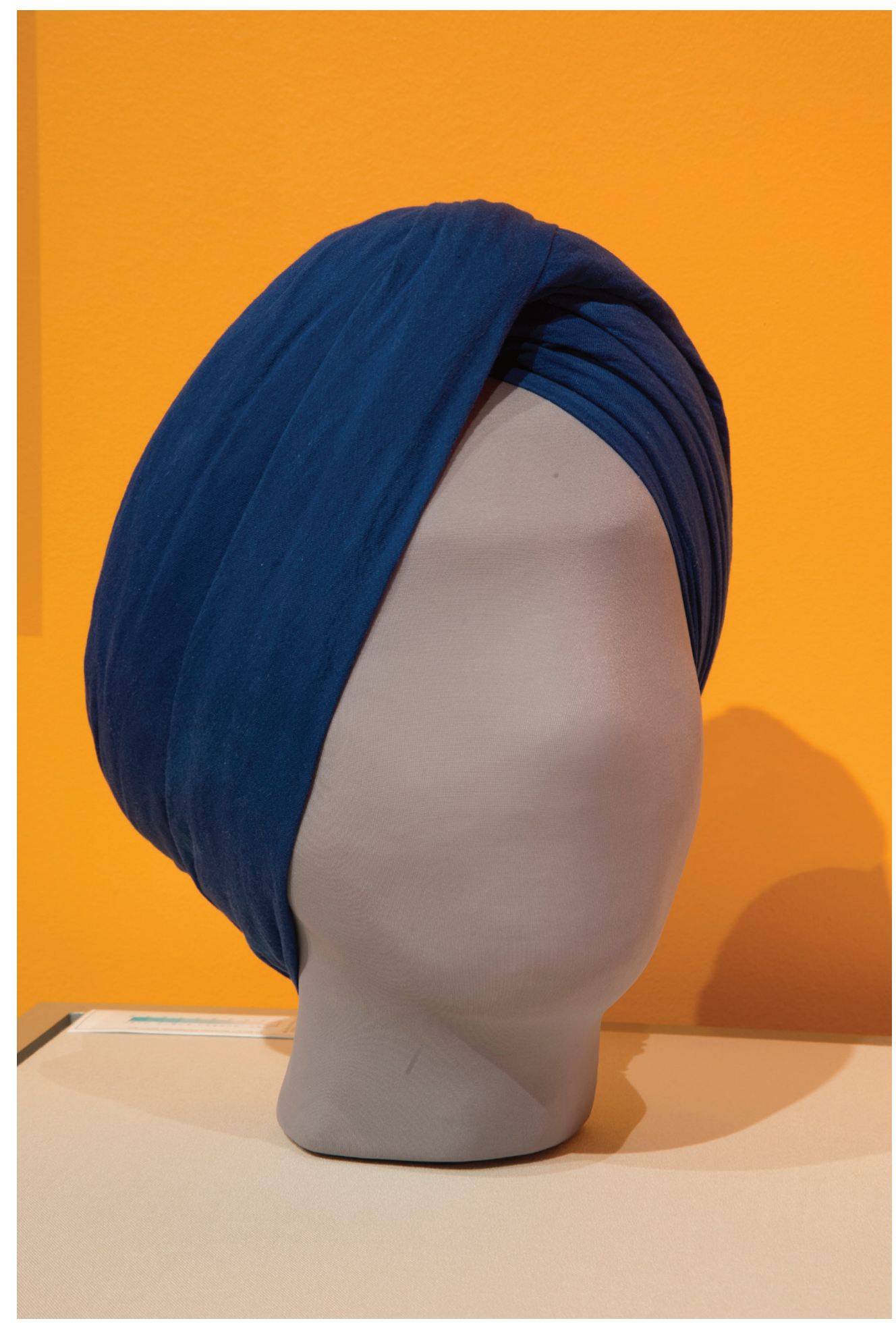

Figure 3. The turban of Balbir Singh Sodhi is on display. Sodhi was shot to death in Mesa, Arizona, on September 15, 2001, in the aftermath of the attacks on the World Trade Center. The turban has been acquired for the permanent collection of the National Museum of American History. Image courtesy of the Smithsonian Institution. 
contemplating what a return would look like. The conflation also suggests a reversal of earlier Asian American practices of cultural avowal, like that of Aiiieeeee!: An Anthology of Asian American Writers (1997), which explicitly claimed "American" identity. Beyond Bollywood makes a similar identitarian claim, but it is interrupted by global India's performative claim on its diasporic subjects.

In 2012, the planned exhibit did not include any works of art. Momaya, who had just been brought on as curator, added three-dozen works of art by "emerging artists," which she hoped would serve a narrative function in the place of text panels and historical objects. For example, she wanted to represent the experiences of Indians on temporary work visas in the United States beyond "analysis, prose and policy debate." She sent out a call for submissions and curated a show, "H1B," for the Twelve Gates Arts gallery in Philadelphia, Pennsylvania. One of the included paintings, Ruee Gawarikar's "The Goddess of Visas," was selected for inclusion in Beyond Bollywood.

Néstor Gárcia Canclini (1999) has shown that while globalization results in the "relative exit" of art from Bourdieu's autonomous fields, this does not mean that artwork loses value as expressive culture. Rather, it gains in symbolic capital through interpenetration with other fields of production. Following Canclini, this section offers juxtaposed readings of three artworks that were exhibited in Beyond Bollywood but not acquired for the Smithsonian's permanent collection. I focus on the symbolic value each accrues through its interpentration with the discourse on New India and the multiple modalities of the exhibit in which it is displayed, and I suggest that Beyond Bollywood registers at the level of the artwork what it either ignores or attempts to neutralize through the display of artifacts: the persistent provocation of a rising India that exceeds, frustrates, and even renders absurd the contours of its diasporic imagining.

\section{Meena Alexander's "Bright Passage"}

Meena Alexander was born in India and raised there as well as in Sudan. She has lived in the United States for over three decades, and describes herself as an "American" for whom America is "completely New York" (Maxey, 27-36). Over the years, she has accounted for her relationship to the Indian American diaspora and its literary canon in generational and familial terms, calling her writing an effort "to remember," in contradistinction to an older immigrant model of writing by "jettisoning the past" (Maxey, 28). The first stanza of Alexander's "Bright Passage," a poem penned specifically for Beyond Bollywood, is inscribed on the opening wall of the exhibit:

"Grandmother's sari, freckles of gold poured into silk, / Koil's cry, scrap of khadi grandfather spun, / I pluck all this from my suitcase -- its buckles dented, zipper torn. / And pictures pressed into an album -- parents by a rosebush, / Ancestors startled in sepia, eyes wide open, / -Why have you brought us here?" That Alexander's poetry of remembrance opens an exhibit that also celebrates the pioneering, past-jettisoning oeuvre of novelist Bharati Mukherjee is an exemplary instance of what I've been calling Beyond Bollywood's contrapuntal narrative. To every artifact that speaks of immigrant assimilation into America, whether arrival into the medical establishment or spelling bee triumph, "Bright Passage" responds with the ancestors' discomfiting query: "Why have you brought us here?"

The poem deals with the issues of immigrant subjectivity, exile, memory, and diasporic consciousness that Alexander has previously explored in numerous volumes of poetry, essays, criticism, and fiction. In The Shock of Arrival (1996), she imagined a 
dialogue between a classical Kathakali dancer playing princess Draupadi from The Mahabharata, and herself, sitting in her room in Manhattan.

"So what brought you here?" Draupadi demands in half-English, halfMalayalam, meaning, why did you come to America?

"Here?" Alexander's character, MA, responds. "Perhaps I came to remember my life...Perhaps I came to make it all up. Name things afresh...to live and write."

"Bright Passage" returns us to this earlier moment in Alexander's corpus, but this time with a focus on the lives and rights of the Indian ancestor, not the Indian American immigrant. "Why have you brought us here?" the startled ancestors ask. Not, "Why have you come here?" Or, "Why did you move to America?" But more pointedly, "Why did you bring us with you? And why don't you let us go?" The poet unpacking her suitcase re-encounters the material artifice of the Indian world she has left: the sari, the scrap of khadi, worn by kin who remain, despite generational and territorial distance, the objects of affective attachment. The suitcase, dented and torn, bears the scars of travel. The album she plucks from her suitcase documents the abandoned world of people and things, as well as suggests the passage of time. But the objects resist the poet; the ancestors' question interrupts her reverie; and one senses that they will not quietly reside in the poet's memory-storehouse of the past.

Theories of diaspora have long engaged the dynamics of arrival and return in equal measure: arrival into welcoming or hostile host countries; return, both psychic and physical, to originary homelands. "Bright Passage" sets a polyphonic tone for an exhibit that speaks to arrival and return, witness and memorial, celebration and correction in multiple voices, but it also calls into question the nature and narration of psychic return to India in the era of Asia's rise--which is to say, the era of reverse migration. The objects the speaker unpacks conjure up an India "past," belying the concurrent transformation of the object world of what is now New India, where khadi has given way to blue jeans, koil's call to call center, sepia to color.

\section{Ruee Gawarikar's "The Goddess of Visas"}

Why have you brought us here, when we have problems there? Why have you brought us here, when we have everything there? Are there words adequate to answer Alexander's ancestors' question? In the spirit of lateral interconnection, I hear a response to "Bright Passage" in Ruee Gawarikar's "The Goddess of Visas."

Less than ten years after Gawarikar's arrival into the United States on an H-4 visa, her painting was selected to participate in Beyond Bollywood. What does the work of a young, unknown artist from India who does not identify as Indian American, an India-born painter who joined her husband in New Jersey in the early 2000s, say in relation to a poem by a self-professed "American" like Alexander? What is going on when both of these artists are asked to speak--indeed, commissioned to do so--in the name of "Indian Americans shaping the nation"?

As discussed in my opening, "The Goddess of Visas" is a commentary on the legal frameworks for migration and the affective structures at work in the pursuit of the visa itself. The painting juxtaposes the depiction of betrayed Indian visa dreams with the phantasmatic iconography of the many-armed Hindu goddess, and in so doing depicts two separate fantasies: a fantasy of the United States, and a fantasy of India. It is not only a commentary on the apparatus of the H1B visa, but on the relations of exploitation inherent in the transaction of human resources (or, humans as resources) between nations. For if a passport can be understood as an instrument of identification, 
then a visa is a technology of permission, inclusion, and exclusion, and the actual Goddess of Visas is not ultimately an Indian goddess, but, as Gawarikar reminds us, an American bureaucrat.

Against the documentary, Americanist grain of the exhibit, Gawarikar's painting is "an interlocutor in a dialogue of equality" (Canclini, 706), which problematizes the narrative of model minority participation in the American economy offered by artifacts like Dham's Pentium chip. The artist, who maintains her Indian citizenship, represents the journey to America not as an idealized future, but through the nightmarish and unavoidable process of visa acquisition. She both exposes the exceptional nature of model minority narratives and shows how outdated the story of Indian brain drain really is, tapping into a widely shared sentiment among young Indian migrants. In fact, a number of the other paintings that Momaya curated for Twelve Gates Arts also offer critical takes on the advertised theme of "H1B," like the Sisyphean trials of Lilaben Leher's "Educated Indentured Servant," who labors up a mountain toward permanent residency while an oversized hourglass empties before his eyes.

Today, Indian students matriculating at U.S. universities and earning postgraduate degrees are more likely than ever to return "home" because a higher standard of living can be attained in India. $86 \%$ believe that "the best days for [India's] economy lie ahead" (Wadhwa, 80) while the predominant attitude regarding the United States is doom and gloom. Returnees to India believe they will be able to take care of parents, be close to friends, and benefit from greater opportunities for professional advancement-that's what they tell researchers, anyway. In one subject's words, "When I left India thirteen years ago [in 1992], all anybody could talk about was 'I want to go to the States'... Now, nobody talks about that. If India was then what it is now, I probably wouldn't have left" (Heenan, 91).

Sejal Patel's "If I were Back in India, Who Would I Be?"

"If India was then what it is now, I probably wouldn't have left." "If I were Back in India, Who Would I Be?"

Sejal Patel is an art teacher and community organizer in Cambridge, Massachusetts, who was born in India but immigrated to the United States as a child. She became a naturalized citizen at the age of ten, and her work in the intervening years has frequently turned on the historical accident of her dual Indian and American identitarian locations. The photographic series, "If I were Back in India, Who Would I Be?" (1996), depicts Patel in staged reenactments of Indian village life both "then" and "now" (Figure 4). The titular promise of "Back in India" suggests the nation of the past, but the conditional "would" reveals that the time in question is the imagined "now" of the photographer's being "in" India. This "now" is arguably 1996, the year the series was created, but both the time and place of the artwork have been recontextualized by the NMNH of 2014. The viewer who encounters the photographs in the second decade of the $21^{\text {st }}$ century is invited into the discursive space of Patel's query here and now; an imagined India of 1996 is made contemporaneous with New India of the present moment.

Momaya's explanatory text attempts to provides context by resorting to an essentialized view of rural India: "If she lived in India, [Sejal's] days would consist of rolling rotis, making yogurt, carrying water, and fetching firewood. But because she lives in America, who can she, and other desi women, be?" The framing question ("if she lived in India") does not qualify the India to which it refers, and the pat answer 
provided ("because she lives in America") reproduces a myth of American opportunity that is doubly self-congratulatory: first, to the non-Indian American viewer, who leaves with misplaced admiration about the personal and professional opportunities supposedly provided women-of-color in the United States; and second, to the Indian American viewer, who leaves feeling smug about having emigrated from India in the first place.
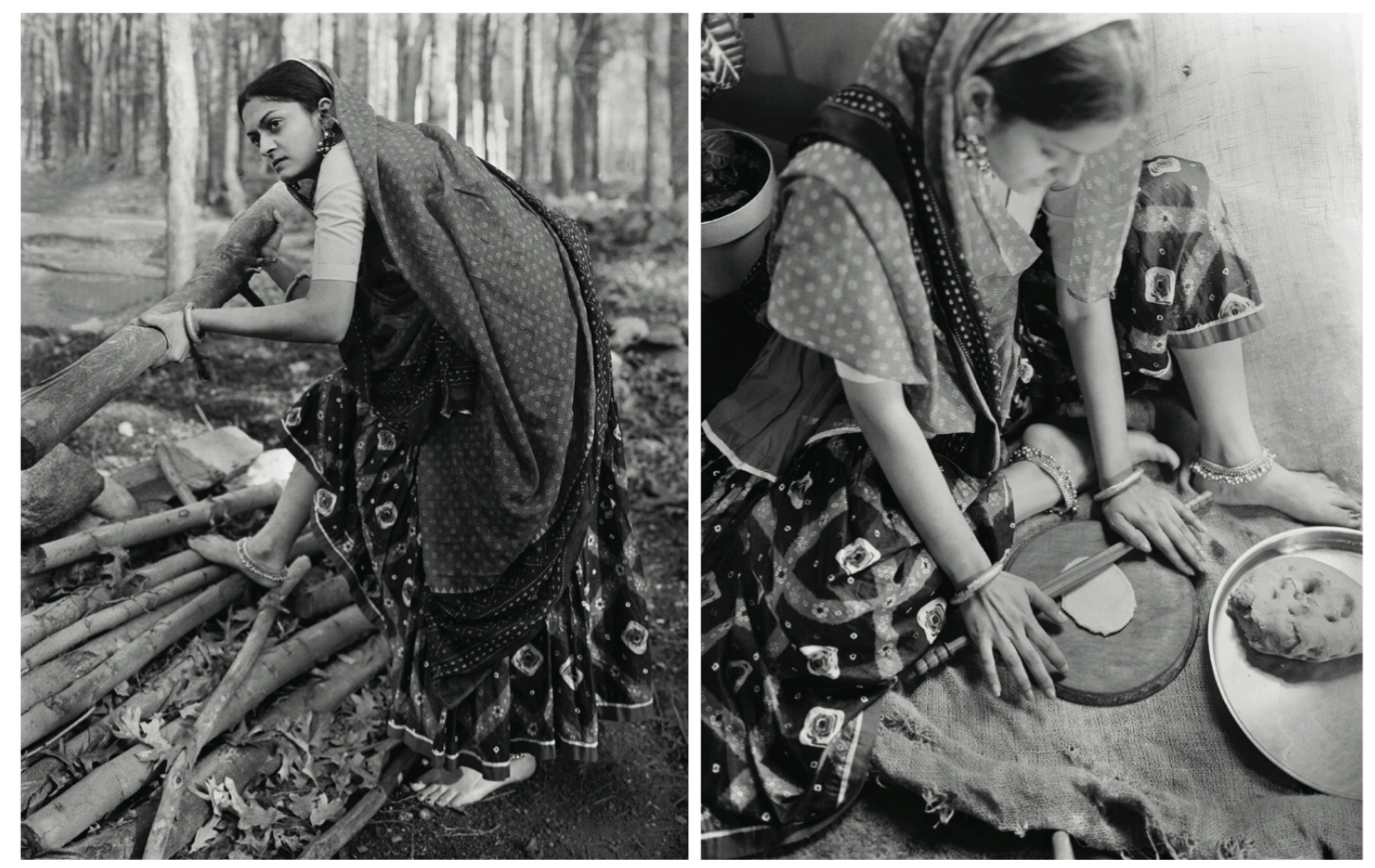

Figure 4. Sejal Patel, If I Were Back in India, Who Would I Be?, 1996. Photographs by permission of the artist.

This is a discordant note for Beyond Bollywood to strike, for more than one reason. First, as I have been suggesting, the phenomenon of diasporic return to India proffers an entirely contrasting response to Patel's titular question. Second, the photographic images of idyllic rural domesticity that comprise Patel's India-present elide the realities of poverty and inequality in New India. If at all India has risen, it has done so on the backs of 800 million rural Indians, whose livelihoods and languages are in danger of extinction. By presenting rural livelihoods (rolling rotis, fetching firehood) as the Indian alternative to the depicted (Indian) American careers of doctors, DJs, and entrepreneurs, Beyond Bollywood not only feminizes Indian labor in general, while exoticizing female labor in particular, but also perpetuates the widespread privileging of non-rural livelihoods in an era of state-imposed urbanization in India and elsewhere.

That being said, Patel's (2012) own artist statement is more nuanced than the curatorial text for this particular work. She describes her art as a process of selfreinvention, an attempt "to recreate the space and time of the 'original' performance" constructed through awareness of the other's "gaze":

In the process of reinventing myself, I wonder about what I left behind...I 
perform as if I am being watched. The awareness of that gaze is what consumes my photographs...I find myself being imagined and re-imagined by none other then [sic] myself... The way we view ourselves is inextricably tied to the way we perceive how society views us, but the way I view myself is what society does not see.

Patel's account of her auto-ethnographic photography suggests that it is not selfOrientalizing, but an illustration of how the colonial-imperial gaze constructs and objectifies a subject who nevertheless maintains her own relation--agential, imaginative, and temporal--to that subjection and its rendering through the image. Following Rey Chow's (1993) respecification of a theory of native agency, Patel's photo "bears witness to its own demolition--in a form which is at once image and gaze" (Chow 1993, 51). The native, Patel, looks back at India and at the viewer not simply as a defiled, essentialized image of feminized Third World labor but with an "indifferent gaze" (Chow 1993, 52), calling into question not the photographer's self-consciousness, but the viewer's, in addition to the perspective offered by the exhibit itself.

In the curatorial framing of Patel's work, Beyond Bollywood approaches the limit of its multicultural narrative of assimilation and cultural preservation. Its representation of Indian American contributions to the United States relies on evidence of the diffusion of India's "soft" power to bolster its own cultural bonafides, on the one hand, and insists on reproducing an essentialist view of Indian domesticity, opportunity, and cultural practice, on the other. With "Bright Passage" and "The Goddess of Visas," Patel's photography evidences the contradictoriness of Indian American return to India in the moment of Asia's rise, as it is ultimately concerned with the double valence of looking back. Beyond Bollywood's attempt to contain India--by assigning it to the past as cultural heritage, as opposed to acknowledging the socio-political and economic challenges New India faces and poses to the world--falters, in what ultimately reads as a parody of developmentalist discourse.

\section{Conclusion: Side-by-Side}

On February 26, 2014, the day before Beyond Bollywood's opening, Congressman Bera stood in the House of Representatives to ask for acknowledgement of the Smithsonian's work in "furthering national dialogue about a community that has become integral to the fabric of American life." That evening, hundreds of donors, community figures, and Washington insiders descended on the NMNH, where they ate aloo tikkis and jumbo prawns, exotic fruit parfait and mini ice-creams, while the Saffron-level donor Kanu R. Shah tried to quiet the crowd before making his presentation. "We are not in India," he chided the audience of VIPs. Bouncers blocked off the bars, and those in line for wine turned, chastened, to face the podium.

Shah did not know it, but his wizened attempt at humor perfectly captured the primary contradictions at work in the exhibit. First, despite its market-driven title, Beyond Bollywood was never supposed to be about India, and the many slippages and conflations between "India" and "Indian American" that I have discussed only underscore the difficulty of disentangling diasporic narratives from ethno-national ones. Second, despite the explicit curatorial aim of detailing Indian American contributions to the United States through the pedagogical labor of the included artifacts, the artworks on display consistently register the diasporic subject's nonpresence in India, the anachrony of diasporic imagining, and New India's resistance to the terms in which the Indian American diaspora speaks its name. 
Today, both the United States and India are heir to the depredations of global finance capital and the pleasures and pitfalls of technological and communicative interconnectivity. The narrative of New India matches the ideological underpinnings of a faltering American dream with its avowal of an equally illusory Indian one, and the East is in many ways the old, familiar West. And yet, as Shah unwittingly noted and I have shown in this discussion, Beyond Bollywood is most interesting for the ways that it registers the affective dissonance of a U.S.-located diasporic subject "left behind" by India's global rise.

Against its documentary mandate, Beyond Bollywood's artworks consistently interrupt the pedagogy of its American Historical artifacts, both aspiring and acquired. Juxtaposed with the "Goddess of Visas," an artifact like Abraham Verghese's doctor bag poses a challenge to the ideology of American exceptionalism. Confronted with the closing query of "Bright Passage," Balbir Singh Sodhi's disembodied turban bespeaks the double bind of diasporic repatriation: the nation that does not protect its minorities may nevertheless appropriate ownership of their stories. The result is an American exhibit that counter-intuitively manifests New India's "indifferent gaze," one that bears witness to the Indian American diaspora's traffic in India's pasts, as each nation moves forward, despite and beside itself.

\section{Bibliography}

Alexander, Meena. 1996. The shock of arrival: Reflections on postcolonial experience. Boston, MA: South End Press.

Anderson, Benedict. 1983 (2006). Imagined communities: Reflections on the origin and spread of nationalism (Rev. ed.). London and New York: Verso. 
Appiah, Kwame A. 1992 (1994). “Identity, Authenticity, Survival: Multicultural Societies and Social Reproduction." Multiculturalism: Examining 'The Politics of Recognition,' 149-63, ed., Amy Gutmann.

Axel, Brian Keith. 2002. "The diasporic imaginary." Public Culture 14, no. 2, 411-428.

Bal, Mieke. 1994. "Telling Objects: A Narrative Perspective on Collecting." Grasping the World: The Idea of the Museum, 84-102, ed. Donald Preziosi and Claire Farago.

Beck, Ulrich. 1986 (translation 1992). Risk society: Towards a new modernity. Vol. 17. Sage. Berlant, Lauren. 1997. The Queen of America Goes to Washington City: Essays on Sex and Citizenship. Durham, NC: Duke University Press.

Bhabha, Homi. 1990. The Location of Culture. London and New York: Routledge. Boo, Katherine. 2012. Behind the Beautiful Forevers. New York: Random House.

Brown, B. 2003. A Sense of Things: The Object Matter of American Literature. Chicago, IL: University of Chicago Press.

Burton, Antoinette. 2007. The Postcolonial Careers of Santha Rama Rau. Durham, NC: Duke University Press.

Canclini, Nestor G. 1999. Imagined Globalization. Durham, NC: Duke University Press.

Partha Chatterjee, The Nation and its Fragments: Colonial and Postcolonial Histories. Princeton: Princeton University Press, 1993.

Chaudhuri, Amit. 2008. Clearing a Space: Reflections on India, Literature and Culture. Oxford: Peter Lang.

Chin, Frank. et al. 1974. Aiiieeeee!: An anthology of Asian-American writers. Garden City, N.Y.: Anchor Press, Doubleday.

Chow, Rey. 1993. “Where Have All the Natives Gone?" Writing diaspora: Tactics of intervention in contemporary cultural studies. Bloomington: Indiana University Press.

-----. 2002. The Protestant Ethnic and the Spirit of Capitalism. New York: Columbia University Press.

Clifford, James. 1988. The Predicament of Culture: twentieth-century ethnography, literature, and art. Cambridge, MA: Harvard University Press.

Cummings, Neil and Lewandowska, Marysia. 2000. The Value of Things. Basel : London: Birkhäuser.

Dasgupta, Rana. 2014. Capital: The Eruption of Delhi. New York: The Penguin Press.

Dhingra, Pawan. 2014. Interview with author.

Ferguson, Roderick. 2012. The Reorder of Things: The University and its Pedagogies. Minneapolis: University of Minnesota Press.

Foucault, Michel. 1978. The History of Sexuality, Vol. I. New York: Pantheon Books.

Genette, Gérard. 1983. Narrative Discourse: An Essay in Method. Ithaca, N.Y.: Cornell University Press.

Grewal, Inderpal. 2005. Transnational America: feminisms, diasporas, neoliberalisms. Duke University Press.

Gusdorf, Georges. 1956. "Conditions and Limits of Autobiography." Autobiography: Essays Theoretical and Critical, 28-48, ed. James Olney. Princeton: Princeton University Press.

Heenan, David A. 2005. Flight Capital: The Alarming Exodus of America's Best and Brightest. Mountain View, CA : Davies-Black Publishing.

Hirsch, Marianne, and Nancy K. Miller. 2011. Rites of Return: Diaspora Poetics and the Politics of Memory. New York: Columbia University Press.

HomeSpun. 2011. "Introductory Packet" 
Jackson, John L., Jr. 2014. Thin description: Ethnography and the African Hebrew Israelites of Jerusalem. Cambridge, Massachusetts: Harvard University Press.

Karp, Ivan, ed. 1992. Museums and communities: The politics of public culture. Washington: Smithsonian Institution Press.

Kirshenblatt-Gimblett, Barbara. 1990. "Objects of Ethnography," Exhibiting cultures: The poetics and politics of museum display, ed. Ivan Karp. Washington: Smithsonian Institution Press.

Kurin, Richard. 2014. Interview with author.

Lowe, Lisa. 1996. Immigrant acts: On Asian American cultural politics. Durham, NC: Duke University Press.

Lye, Colleen. 2005. America's Asia: Racial Form and American Literature, 1893-1945. Princeton, NJ: Princeton University Press.

----. 2015. “Unmarked Character and the Rise of Asia," Verge (forthcoming)

Markowitz, Fran and Anders H. Steffanson, eds. 2004. Homecomings: Unsettling Paths of Return. Lanham, Md.: Lexington Books.

Maxey, Ruth, and Meena Alexander. 2006. "Interview: Meena Alexander." MELUS, 2139.

Mehta, Parag. 2014. Interview with author.

Momaya, Momaya. 2014. Interview with author.

Mukherji, Dhan Gopal. 1923. Caste and outcast. New York: E.P. Dutton \& Company.

Narayan, Shoba. 2012. Return to India: An immigrant memoir. Jasmine Publishing.

The Oxford English Dictionary. 2014.

Parry, Benita. 1994. "Signs of our times: Discussion of Homi Bhabha's the location of culture." Third Text 8.28-29, 5-24.

Patel, Sejal. 2012. "Artist Statement," Available online from $<$ http:/ / patelsejal.com/Patel_MyArt_Statement_2012.pdf>

Prashad, Vijay. 2000. The Karma of Brown Folk. Minneapolis: University of Minnesota Press.

Pratt, Mary Louise. 1991. "Arts of the Contact Zone," Profession, 33-40.

Ricciardone, Chiara. 2014. "Plato's Pathologic" (unpublished dissertation)

Roy, Arundhati. 2014. Capitalism: A Ghost Story. Chicago, IL: Haymarket Books.

Said, Edward. 2000. Reflections on Exile and other essays. Cambridge, MA: Harvard University Press.

Schlatter, N. Elizabeth. 2010. "A new spin: Are DJs, rappers and bloggers 'curators'?" Museum (January-February): 49-55.

Srinivasan, Ragini Tharoor. 2014. “Whose currents?" HimalSouthasian, Vol. 27, No. 4, 1222.

Stewart, Susan. 1984. On longing: Narratives of the miniature, the gigantic, the souvenir, the collection. Baltimore, MD: Johns Hopkins University Press.

Taylor, Charles. 1992 (1994). "Multiculturalism and 'The Politics of Recognition'” Multiculturalism: Examining 'The Politics of Recognition,' ed., Amy Gutmann.

Tsuda, Takeyuki. 2009. Diasporic Homecomings: Ethnic Return Migration in Comparative Perspective. Stanford, Calif.: Stanford University Press.

Verghese, Abraham. 1997. "The Cowpath to America," New Yorker (June 23 \& 30), 70-88.

Wadhwa, Vivek, 2009. "An Outflow of Talent: Nativism and the U.S. Reverse Brain Drain," Harvard International Review.

Xiang, Biao, Brenda S. A Yeoh, and Mika Toyota. 2013. Return: Nationalizing Transnational Mobility in Asia. Durham: Duke University Press. 